\title{
5. Campanella and Bacon: Concerning Structures of Mind
}

Knowledge is the action of the soul, and is perfect without the
senses, as having the seeds of all science and virtue in itself; but not
without the service of the senses; by these organs the soul works:
she is a perpetual agent, prompt and subtle; but often flexible and
erring, entangling herself like a silkworm: but her reason is a
weapon with two edges, and cuts through. -Ben Jonson, Discoveries

The compass opened, if I may so express myself, the universe.

-Montesquieu, De l'esprit des lois

"The first century of modern science," to use Whitehead's phrase once again, opened in Italy with two martyrdoms, not one. On February 7, 160o, ten days before Bruno was burned at the stake in Rome, the civil authorities in Naples began their interrogation of Tommaso Campanella. In June, still holding out against the savage torture he was being made to undergo, the utopist started to feign madness. By such means he could (and did) avoid the almost certain death penalty that would be the reward for his leadership of the Calabrian conspiracy against Spanish rule. An insane person could not be shriven, and could not therefore be executed. Campanella was to spend the next twenty-eight years in a confinement that fluctuated between the almost unbelievably harsh and the relatively gentle.

These two martyrs were both equally at odds with the old and the new. Both teetered in the gap betwen an old discourse of analogies and a new one of analysis. But no longer were these presented as contradictory elements within a single class of discourse, or even as a class and a 'subclass' of emergent elements. More's paradoxes and the emergent solution of them in Kepler had now led almost to a situation where a choice was possible. Both Bruno and Campanella 168 
claimed to see direct observation as the means to a complete knowledge of things. Thus we might imagine they held views and wrote in a manner akin to what we find in a Galileo or a Bacon. We would be mistaken: their choice was not the same.

In both Bruno and Campanella the term 'direct' tends to imply some form of nonmediated knowledge. At the same time, the term 'complete' refers us rather to a knowledge having to do with the Divine: indeed, to a kind of 'immediate awareness' of the Divine in all things akin to that 'organic participation' we have already seen. Their goal is not a gradual analysis of things with a view to their potential use, but rather a kind of accumulation of all possible elements of knowledge leading to some 'union,' to some conjunction within an all-embracing totality: "For in this condition of ours we cannot desire or attain greater perfection than that which is ours when our intellect through the medium of some noble intelligible species is united either to the separate substances, as some say, or to the divine mind, if we employ the idiom of the Platonists."'

It is significant, moreover, that Bruno's De gli eroici furori, from which I have just quoted, is couched in the terms of a variant of the schoolmen's fourfold interpretive reading of a group of poems and emblems. Such an unfolding of meanings forms part and parcel of the 'directness' and 'completeness' in question. "They say," adds Campanella concerning his Solarians, "that it is first necessary to look at the life of the whole and then at that of the parts." ${ }^{2}$ We might find ourselves inclined to affirm that the entire Città del sole is an illustration of Bruno's assertion.

Here, reason guided by the will is not going to lead us to the use of things and to power over them, nor is it going to conduct us to

1. Giordano Bruno, The Heroic Frenzies [De gli eroici furori, 1585], ed. and tr. Paul Eugene Memmo (Chapel Hill, N.C., 1964), p. 117 (pt. I, 3d dialogue).

2. Tommaso Campanella, La città del sole, in Opere di Giordano Bruno e di Tommaso Campanella, ed. Augusto Guzzo and Romano Amerio (Milan and Naples, 1956), p. 1098. References to the Italian will be to this edition, indicated in the text by an I, followed by the page number. The Italian text was begun in 1602 , and was translated, somewhat adapted, into Latin for its appearance as the Appendix politicae civitas solis idea reipublicae philosophiae, following Campanella's Realis philosophiae epilogisticae partes quatuor ... (Frankfurt, 1623), pp. 417-64. The only English translation is by T. W. Halliday, which can be found in at least three anthologies. I have used Henry Morley, Ideal Commonwealths (London and New York, 1901): references to this will be indicated by an $\mathrm{E}$, followed by the page number. The translation is not good: it is abridged and of ten rearranged in places where the translator has censored 'indecent,' theological, astronomical, and astrological discussions. In my text, therefore, the English reference will sometimes be lacking, and in such cases the translation is my own. I have also made use of the excellent modern French translation, La cité $d u$ soleil, ed. Luigi Firpo, tr. Arnaud Tripet (Geneva, 1972). 
the greater material comfort of a section of humankind. This kind of reason is to bring the human soul to unity with the divine whole. Such is the revelation of The Heroic Frenzies, and such is what is illustrated in the very construction of The City of the Sun.

According to Marx, the utopian thinker writes as a bourgeois, who in the silence of his study gives free play at once to his reason and his imagination. ${ }^{3}$ One might suppose that this assumed (psychological) duality of cause is reflected in the result. For the utopian ideal (at least after More) is at once a meditation upon history or a historical situation, which could be thought of in that respect as scientific, and the proposal of an 'ideal' solution that would close and eradicate history.

Of course, on the one hand one can hardly refer to Campanella as writing "in the silence of his study," while on the other no utopia can be scientific in the Marxian sense. For they are comparable only to thought experiments, which have been isolated from the particular sociohistorical situation that alone could make them scientific. I am not, however, as Marx and Engels were, concerned with the applicability of the content of such documents: in that regard Engels is perhaps justified in dismissing them as "phantasies" which may be left to "the literary small fry to solemnly quibble over." here is with the discursive functioning that produces such 'content,' that directs and controls it. I am assuming that it is a functioning that organizes at the same time the dominant forms taken by most other types of discourse produced in the same time and place: sociopolitical, economic, philosophical, scientific, critical, and the rest.

Utopian texts conceived as containing some kind of discussion about a historical situation may well be reckoned to be unusable

3. Paraphrased by Georges Duveau, Sociologie de l'utopie et autres "essais" (Paris, $1961)$, p. 7 .

4. Friedrich Engels, Socialism: Utopian and Scientific, in Karl Marx and Friedrich Engels, Selected Works (New York, 1968), p. 403. See also The Communist Manifesto, ibid., p. 61. Such a view of the 'scientific' is combatted, at the same level of content, by Karl R. Popper in The Poverty of Historicism (New York and Evanston, 1964). Popper argues that all science works on more or less isolated experimental systems, and implicitly, therefore, would consider utopias to be valid as social (thought) experiments. They would indeed, he asserts, be more 'scientific' than the holistic approach of dialectical materialism, which constructs its theory of the development of the state, according to Popper's reading, from an a priori set of hypotheses concerning a particular and unique human history on the pretense that they are universal laws. This strikes me as a willful misreading of Marx, who seeks to show that human history is a developing set of coherent and traceable relations: they are not conceptual a prioris but observable realities. This gets us into problems with which we are not immediately concerned here, but the dispute in itself is worth noting as a significant example of the point of view from which written utopias have always been considered (by 'literary' as well as social or political critics). 
fictions. But that cannot change the fact that as discursive practice they are necessarily one of the elements of the semiotic field that is the episteme in which they function. Their ordering will reproduce that of a specific ideology: "The domain of ideology coincides with the domain of signs. They equate with one another. Wherever a sign is present, ideology is present, too. Everything ideological possesses semiotic value." In that sense it is impossible to separate any discourse from the social situation (for example) which makes it possible and for which it is in turn partly responsible: "the sign and its social situation are inextricably fused together. The sign cannot be separated from the social situation without relinquishing its nature as sign." ${ }^{5}$

To the extent that the utopia formulates an ideal 'out of history' at the same time as it presents a reasoned attempt to permit the insertion of that 'non-time' into the stream of a recognizable and localized history, it partakes of that discursive division characteristic of the European sixteenth and seventeenth centuries. In this it is comparable to science fiction-though I know of no utopia that seems to 'overcome' the split in the way Kepler's Dream does. Utopias seem rather to fall neatly onto one side or the other of the epistemic gap-though the complexity of their nominal origin, Utopia itself, makes of it the special case already examined. None other, of course, falls at a moment of such a crisis in discourse. Subsequent utopias always appear to make the choice which I have mentioned.

In so far as a utopia is 'dynamic,' as is the case of Bacon's New Atlantis (1627), it offers a kind of construction and continuation of history: an open-ended series which may be said to be adapted to the process of analytical thinking. When a utopia is 'static'-a term appropriate to The City of the Sun (1623) or to Andreae's Christianopolis (1619), for example-it suggests that halt to history to which I have just referred. Such a 'halt' is always found in the shape of a 'myth,' characterized by what one can only call a completeness of knowing and the known, a kind of fullness of being. In a way, just as the Marxians can argue that no utopia can be scientific, so it can also be asserted that utopias are always static -as Alexandre Cioranescu has done. ${ }^{6}$ For such texts always suggest to some extent the sublimation

5. Valentin Nikolaevič Vološinov, Marxism and the Philosophy of Language, tr. Ladislav Matejka and I. R. Titunik (New York, 1973), pp. 10, 37 (original Russian edition, 1929).

6. Alexandre Cioranescu, L'avenir du passé: Utopie et littérature (Paris, 1972), p. 23: "The very structure of the genre forces it to remain within horizontal structures, in which epic details provide only an artificial relief: the great enterprise of vertical or diachronic cross-sectioning is not open to it." It is not therefore to be wondered at that he finds himself obliged to add later: "One may say that Bacon's utopia is not utopian" (p. 149). 
of an existing social order in which they are nonetheless said to find their origin, or at least of some model abstracted from that order.

That a distinction can be made, however, between the static and the dynamic utopia, and that for the period with which I am concerned here such a distinction corresponds to that between patterning and analysis, is one of the things I hope to be able to show. For the two best-known utopias of the early seventeenth century represent an almost exemplary demonstration of two different classes of discourse in collision. Campanella's City of the Sun stands virtually as the paradigm of knowledge by analogies, resemblance, or the formation of patterns. Bacon's New Atlantis is the epitome of the new experimentalism, of the search for knowledge by a process of induction, by analysis and reference.

To be sure, Campanella was anything but ignorant of the expanding knowledge and technical know-how characteristic of his age. $\mathrm{He}$ is aware in some detail of the voyages of discovery: his dialogue between the steersman and a "Grandmaster of the Knights Hospitallers" is reminiscent of Pigafetta's relation of Magellan's voyage to the Grandmaster of the Knights of Rhodes. ${ }^{7}$ His seamen served with Columbus, his Solarians have discovered flight, various forms of sea and land travel, and diverse other mechanical devices. ${ }^{8}$ He hesitates between the systems of Ptolemy and Copernicus (I 1108; E 177), avoids pronouncing on the delicate question of the infinity of worlds, one of the charges brought against Bruno (I 1110-11; E 179), and refuses authority in learning, declaring a preference for the direct experience of things (I 1081; E 151-52). ${ }^{9}$ All this may be gathered from even the most superficial reading of the utopia itself. Campanella was also, of course, so ardent a supporter of Galileo as to offer himself in 1632 as the scientist's defender before the papal commission, and he had previously risked his life and successfully put a stop to the process leading to his own freedom by his Apologia pro Galileo (1622, begun in 1616 , the year of the first ecclesiastical injunction against Galileo). In that text he had, as De Santillana puts it, "called Aristotle and the Scholastics all sorts of names, had come out boldly for the Copernican system, and had propounded new and arbitrary interpretations of scripture."

7. See Charles E. Nowell, ed., Magellan's Voyage around the World: Three Contemporary Accounts (Evanston, 1962), pp. 85-260.

8. These last two details are omitted by Halliday.

9. This summary obviously does gross injustice to Campanella's thought as a whole, but I am concerned here in the main with what can be gleaned from The City of the Sun. For the rest see, for example, Léon Blanchet, Campanella (1920; rpt. New York, n.d.). 
Nonetheless, as De Santillana elsewhere observes, these particular "perilous fantasies" serve Campanella rather to affirm than deny that science is the handmaiden of a humanism based in theological speculation. ${ }^{10}$ Scientific discoveries are more or less satisfactory explanations, in the form of geometrical constructions, of the myriad workings of divine providence. Such discoveries are, that is to say, parts of the divine whole, union with which is the goal of life. Campanella's Solarians seek, as Luigi Firpo puts it, "the constitution of an organic and universal knowledge." The entire city is shaped in terms of such an 'encyclopedia,' whose center and soul is the sign of God Himself, the Sun.

The Copernican system struck Campanella as a particularly happy model. In that he differs scarcely at all from Osiander's position in the preface to the De revolutionibus. He accepts the new cosmology as a suitable mathematical model for purposes of human knowledge but denies that it is reality. ${ }^{12}$ This position, Renaissance humanist rather than anything else, is the very echo of the mode of thinking of the pre-Galilean philosopher. Speaking of Urban VIII, De Santillana makes the following remark:

This is where his thinking was backed by the great schemes of the Renaissance and its hope in unknown harmonies. "There is nothing that is incredible," Marcilio Ficino had said. "For to God all things are possible, and nothing is impossible. There are numberless possibilities that we deny because we do not happen to know them." This was also what Pico della Mirandola had maintained, hinting at reaches of "natural magic" beyond our dreams; and Campanella, too, was supporting Galileo in the hope of results such as no scientist could ever produce. It was "Platonic theology" itself, urging man to extend his imagination beyond what he could see and test; it was Leonardo's belief in the creative power of artistic "fantasy." 13

When Bruno writes that "the most brilliant and the most obscure, the beginning and the end, the greatest light and the most profound

10. Giorgio de Santillana, The Crime of Galileo (Chicago, 1959), p. 199 n. 7; pp. 19, 168.

1 1. Luigi Firpo, La cité du soleil, p. xxiii.

12. See Blanchet, Campanella, pp. $244 \mathrm{ff}$. Campanella writes: "Before presenting in Chapters IV and V the arguments from ancient and modern theologians which support and oppose Galileo, I shall construct from Holy Doctrine, the law of nature, and the agreement of mankind, the most probable and substantial hypotheses or foundations essential to their foundation" (The Defense of Galileo, tr. and ed. Grant McColley [Northampton, Mass., 1937], p. 14; my italics).

13. De Santillana, Crime of Galileo, pp. 167-68. 


\section{4 . The Discourse of Modernism}

darkness, infinite potency and infinite act coincide," ${ }^{4}$ he is expressing a viewpoint essentially similar to what lies behind Campanella's criticism of scholastic learning, when the Solarians argue that the bookman "has contemplated nothing but the words of books and has given his mind with useless result to the consideration of the dead signs of things" (I 1082; E 151). ${ }^{15}$ This is little different from their (and Campanella's?) acquiescence in the Copernican system:

They praise Ptolemy and admire Copernicus, but put Aristarchus and Philolaus ahead of him. But they say that the one does the reckoning with stones, the other with beans, but none with the things themselves that are counted [le stesse cose contate], and that they pay for the world with calculating chips [li scudi di conte], not with gold. But they research this business [questo negozio] with much subtlety, because it is important to know the construction of the world. [I 1108 ]

The signs of things serve only to conceal them. Between the bookmen's activity of playing with the signs for themselves (say the Solarians) and that of the future technocrat who will take the signs for their referent, the choice is that of one side or the other of the same coin. The choice is visible (as it was not before), but it lies between two evils. The phrase "stesse cose contate" is a revealing one. It presents the goal to which the Solarian will bend his energies: a knowledge of things in themselves, without the mediation of signs, whether these be monetary, linguistic, or any other.

The Solarians have incorporated the elements of this knowledge within the very code through which their city is built. The gradual deciphering of these material elements will conduct the Solarian to the temple at the center of the city, where Sol is to be found, symbol of unity with the Divine. The world cannot therefore be ordered by humankind for its own use, because humanity is simply one further bit (debris, perhaps) among all the many to be pieced together. Like Kepler, the Solarian plays with shapes and figures that compose a plan of whose overall structure he is ignorant. Nonetheless, and again like Kepler, he fits some of them together into a discourse for whose order he $i s$ responsible, hoping thereby to fulfill a goal similar to what Andreae's Director of Learning proposes: "for he insisted that a close examination of the earth would bring about a proper appreciation of the heavens, and when the value of the heavens had

14. Bruno, Heroic Frenzies, p. 77.

15. The Italian is briefer: "perché non contempla le cose ma li libri, e s'avvilisce l'anima in quelle cose morte." 
been found, there would be a contempt of earth." ${ }^{\prime 6}$ The City of the Sun is an attempt to place heaven on earth, to inscribe all possible "pieces of the world' into the order of its own construction. From this point of view it makes not the slightest difference whether the city's plan is to be found in the pages of a book or executed in stone in the hills of Calabria (as Campanella had indeed tried to do, before writing the text).

The city thus looks back to the Great Chain of Being for the ordering of the knowledge it contains, and to the Critias and the earlier Renaissance utopias of Doni and Stiblin for the outward shape of its succession of circular walls. The structure of the Città del sole directs the traveler inward, and ultimately through the microcosm that it is, to the infinity of the Divine that it seeks to produce. ${ }^{17}$ It is not therefore surprising that its theme appears directed to a future and to a knowledge of the natural sciences: "It represents an unlimited will to know [Wissen-Wollen], which is directed at all natural objects." 18 "Appears" is the operative word, however. Such knowledge of nature is not simply a "will to know." It is the will to know God-in the very strongest theological sense of knowing. To this end the Solarians direct all their science. It cannot, therefore, be directed toward a future in any historical sense, for the Deity is not accessible to such a concept of 'natural' (or humanly ordered) history.

The Solarians are striving to put together the pieces of an everexistent total order which subsumes them within its fabric. Perhaps such a totality is what is contained in the book written "in letters of gold of most important things, kept in the center of the temple" (I 1075; E 144). Of this book nothing more will, or can, be said. No doubt it is akin to the "cyclical" book of Borges's "Library of Babel," containing all possible knowledge, all possible forms of sense and of nonsense-in short, all discourse. And which is God. ${ }^{19}$ Thomas More

16. Johann Valentin Andreae, Christianopolis [Reipublicae Christianopolitanae descriptio, 1619], tr. and ed. Felix Emil Held (Urbana, Ill., 1914), p. 187.

17. See, e.g., Charles Rihs, Les philosophes utopistes: Le mythe de la cité communautaire en France au xviie siècle (Paris, 1970): "The City of the Sun, a political work, is a description of the ideal State, an image of the divine order" (p. 293). Or again: "The Solarian approaches knowledge more as a Platonic philosopher than as an expert technician" (p. 299 n. 8).

18. Martin Schwonke, Vom Staatsroman zur Science Fiction: Eine Untersuchung über Geschichte und Funktion der naturwissenschaftlich-technischen Utopie (Stuttgart, 1957), p. 10 .

19. Jorge Luis Borges, "The Library of Babel," in Labyrinths: Selected Stories and Other Writings, tr. and ed. Donald A. Yates and James E. Irby (Harmondsworth, 1970), p. 79. Michel Foucault has written some parallel remarks on this matter in "Le langage à l'infini," Tel Quel, 15 (1963), 52-53. 


\section{6 - The Discourse of Modernism}

had sought to elaborate such 'wholeness' in his text, and found himself confronted with insoluble contradictions. Campanella is content to intimate something of the kind and then forget it.

The city "is divided into seven rings or huge circles named from the seven planets, and the way from one to the other of these is by four streets and through four gates, that look toward the four points of the compass" (I 1074; E 141). After the visitor has entered through the outer walls, of which the traveler remarks that "so thick are the earthworks and so well fortified ... with breastworks, towers, guns, and ditches" (I 1074; E 142) that they would be impossible to storm, he passes through the subsequent rings and arrives at the foot of an ascent. "On the top of the hill is a rather spacious plain, and in the midst of this there rises a temple built with wondrous art" (I 1075; E 143). Like the Athenian Acropolis or the theocratic medieval discursive model, this summit embodies the mind of the civil society whose high point and center it is. The temple is not divided from the city but like the intellect or, perhaps, the soul (anima) it incarnates, it is opened up to it. A constant intercommunication can take place: "it is not girt with walls, but stands upon thick pillars, beautifully wrought," while at its center is to be found the dome with the altar beneath (I 1075; E 143). The occupants of the temple are the forty "priests and religious of ficers" (I 1075; E 144: the number is forty-nine in the Latin) of whom the principal is Sol..$^{20}$

Sol is a godlike figure, all-knowing, analogous to the Borgesian book, the ideal of both Bruno and Campanella: he "is, as it were, the architect of all science, having rule over all. . . . Sol is ashamed to be ignorant of any possible thing" (I 1102; E 171: my italics). A far cry, this, from the ideal of a later scientist, who might well be ashamed of not trying to get to know everything, but certainly not of not actually doing so. Indeed, the priests, who are named after various human virtues, moral, intellectual, and physical, are described in a rather revealing manner. They are essentially the mediators between ordinary citizens and the government of Sol: "The priests, moreover, determine the hours for breeding and the days for sowing, reaping, and gathering the vintage, and they are, as it were, the ambassadors and intercessors between God and man" (I 1106 ; E 175). ${ }^{21}$

20. It may be noted that all the Italian MSS have the astrological sign $\odot$ for the name of the Metaphysician: the first Latin edition transcribes this as Sol, the second as an $o$ preceded and followed by an $h$. The English translation has used Hoh throughout. I have replaced this in every case by Sol.

21 . The Italian reads, "e serveno come mezzani tra Dio e gli uomini." 
The ordering of the city is such that the traveler passes through the material walls to the pure intellect and soul at the center, and it is this structure that informs life within the city in all its forms and at all levels. The learning process itself is impressed upon the citizens by its means. The rejection of mere signs is a further indication of such a process, though their necessity for purposes of communication is recognized. The purely human symbolic languages of alphabet and mathematics are relegated to the fortified outer wall that would be the first to fall (though mathematics are given pride of place on its inner surface): for while the way to knowledge must initially lie through the outer skin, the learner must, so to speak, come through to the inside. As in Andreae's city, the observation of earthly signs is simply a moment in the passage to the unity of all things in the Divine (that being, in this sense, simply a way of patterning-necessarily, for in this conception any discourse can only be a piece of such overall plan). The alphabets are accompanied by the image of the whole earth on that same outer wall. Things are finally learned, not by talking about them, but by a direct observation of their images: that is to say, "by walking around them" and through them (I 1080; E 149).

Such symbols are replaced, as the visitor approaches the inner temple, by the depiction of natural objects (successively minerals, rivers and streams, vegetables, birds, and animals), until he comes to "the mechanical arts" and "the inventors in science, in warfare, in law" (I 1077; E 146), the prophets of natural religion, and arrives at last at a final resolution of the microcosm/macrocosm tension with the world on the altar, where is also to be found the soul/mediator, the ruler of the City of the Sun. The sun (who is also Sol, of course) is worshiped as the image of God, placed as it is in the heavens as His most visible sign (I 1 109; E 178). It is at the same time the center of the city and the soul which receives illumination from the Divine. Anima as patterning operator seems clearly visible in this organization.

We are also very close, once again, to Bruno, who likewise uses the sun as a metaphor (and more) for the soul. The eye of the mind receives the light of God and translates it into love: "All love proceeds from the sight, intellectual love from the eye of the mind; sensible love from the view of the senses. [Sight] is not desired for itself, but surely because of some object, inasmuch as the apprehension of an object cannot take place without it." ${ }^{22}$ Heart and eyes,

22. Bruno, Heroic Frenzies, pp. 131-32. For the sun as soul, see p. 137. The entire fourth dialogue of the first part is devoted to this discussion. 


\section{$178 \cdot$ The Discourse of Modernism}

intellect and soul produce a kind of 'dialectic' of knowledge tending toward that unity of which I have already spoken. Through the eyes (whether physiological or spiritual) the object kindles desire, and that desire creates a dialectic whose object is to efface itself in a complete and perfect knowledge. And Bruno concludes his Heroic Frenzies with an allegory concerning the nine ways in which their humanity makes men blind to the light proceeding from "the divine object." ${ }^{23}$

Campanella's city is a kind of practical version of the "Song of the Illuminated" with which Bruno concludes the dialogues called De gli eroici furori. ${ }^{24}$ It is a world in harmony, whose outer wall reveals "an immense drawing of the whole earth" (I 1076; E 145) and whose inner space is occupied by the image of the Divine and the seat of unity, at once political and spiritual, intellectual and material. Between them lie all the bits and pieces that make possible such a pattern. That it must always remain to some extent imperfect, that it must admit the possibility of finding a more appropriate contender for the position of Sol than the person presently occupying it, is the mark of an ordering that considers itself to be receiving its light from beyond. It views itself as striving to compose a whole from an accumulation of parts, under the inevitable constraint of being itself just one more such part. The Solarians sum up this situation in one of their pieces of wisdom: "The world is a great animal, and we live within it as worms live within us" (I $1110 ; \mathrm{E} 178)$. One is tempted to recall Kepler's similar affirmation.

This plan and the harmony are fixed. They compose a variant of the older order of the Scholastics. It is by a logic in perfect accord with such an order that the city is communistic, and not at all as a prophecy of things to come. Here the dynamism of the individual, the impulse behind possession, the imposition of will have no role. It is not an accident that Campanella's system was originally planned and started as a dwelling place for and with the participation of many people (the Calabrian revolt), before it became a writing for the contemplation of the individual reader (and written in the solitude of prison).

What is depicted on the walls are the pieces of a static natural grandeur that is neither controlled by man nor controls him. It informs all activities and the entire system of the city. To be sure, there is a social hierarchy within the city (albeit very underplayed), but within each step there is equality of possession (though the

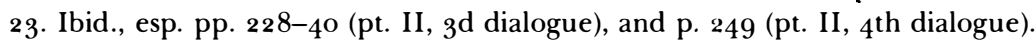

24. Ibid., pp. $265^{-66}$ (pt. II, $5^{\text {th dialogue). }}$ 
Solarians are uninterested in material possession in any case) if not of talent: and each talent, too, has its proper and permanent place in that organized hierarchy. This is precisely the theocratic model of certain medieval discursive theory. Given the static form of things, all work in harmony (and the pieces can be ordered indeed only because they do not change according to a willful human ordering). It is to be expected that things are done by the inhabitants only "when it is a pleasure to them" (I 1097 [con gusto]; E 167 ), and because it is natural to do so (I 1089; E 158): "each one according to his natural propensity [does] his duty well and pleasantly, because naturally" (I $1094 ; \mathrm{E} \mathrm{158)}$. The harmony of the natural extends to include mankind.

Campanella's city is a kind of static refuge (not, I would insist, a retreat) from the problem posed by an episteme on the verge of confirming the adaptability of a discourse of analysis and reference, of imposing a 'light' entirely human rather than accepting illumination from the outside, of affirming the difference between thinking man and material substance taken as 'outside' his intellect. It is, remarks one commentator, "an enchanted island, miraculously preserved at the Ocean's end, a perfect ark rediscovered at the end of a dream." ${ }^{25}$ Still, the Solarians are well aware of new developments. They seem bent on seeking knowledge: "And when I asked with astonishment whence they had obtained our history, they told me that among them there was a knowledge of all languages, and that by perseverance they continually sent explorers and ambassadors over the whole earth, who learn thoroughly the customs, forces, rules and histories of the nations, bad and good alike" (I 1077; E 147).

Yet this 'dynamism' is absorbed into the monolithic structure of the city, just as the planetary laws were absorbed into Kepler's universal harmony. They are absorbed as a potential force for change into a form that can accept no change. Where the harmony is perfect, the only hope for 'survival' is, quite precisely, no change. The knowledge brought back from these searches becomes just so many more bits and pieces to be inscribed upon the walls. The circles that are at once the order of knowing and the order of the world that is known, cannot but predicate their essential identity and constancy. That is why the movement to knowledge, the visitor's passage through the walls, is inward. It is directed toward the divine intellect, toward the soul, into the static knowledge and unity at the center of 


\section{0 . The Discourse of Modernism}

being. There, all the bits and pieces of the world, through whose ordered inscription on the walls the traveler has passed, lose their multiplicity and partiality. A performance such as this in the early seventeenth century was, I submit, already almost archaic, distinctly conservative, the mark of a residual discourse.

Speaking of the necessary structure of all utopian fiction, Cioranescu has noted that its articulation is most similar to that of a lawyer's brief: "The hypothesis is its basic fact: the deduction is its logical scaffolding." ${ }^{26}$ This forms the whole fiction: the static construction presented in the form of a closed and finished city. Now while this may not be a wholly inapt characterization of La città del sole, of Christianopolis, or even of Utopia itself (though it tends then to become a meaningless generalization), what are we to do with it when the fiction makes deduction (or induction) not merely the means of its scaffolding but its very subject? A recent utopia such as B. F. Skinner's Walden Two (1948), for instance, sets the idea of logical (experimental) progress at the very foundation of its functioning. And what is most frightening for us about Brave New World or 1984 is just exactly their static, sealed nature, and the quashing of the hope of experimentalism by extending it to its logical limits. There seems no a priori reason why the discourse of utopia should present a lack of movement, even though it shares the general aim of all analytico-referential discourse and therefore embodies the process/entropy contradiction.

Sir Francis Bacon lies at the other end of Huxley's and Orwell's dreary ladder, and in New Atlantis it is perhaps not surprising that a serial process should become its own subject. James Spedding, in his introduction to New Atlantis, remarks that while Bacon had only to write down "as known all that he himself most longed to know" in order to show the ideal result of the experimental labors of his state, yet "he could not describe the process of a perfect philosophical investigation" because he had not yet expounded such method in the Novum organum. ${ }^{27}$ I would suggest that such a view reverses the necessary priorities, and that a discursive practice in fact precedes the formalization of such a method as content.

New Atlantis actually does the opposite of what Spedding claims.

26. Cioranescu, Avenir du passé, p. 25. This position is taken by most commentators of utopian fiction.

27. The Works of Frances Bacon, ed. James Spedding, Robert Leslie Ellis, and Douglas Denon Heath, 15 vols. (Boston, 1861-64), V.35o. The text of New Atlantis occupies pp. 359-413 of this edition. Future references in this chapter will be indicated in the text by page number only. 
That aspect is what contrasts most clearly with La città del sole. While the prospective content of knowledge is by no means a given (as it would also be according to Cioranescu's characterization), the discursive process by which it may be achieved is shown quite clearly, even if it is not spelled out (or said) in all its formalized detailswhich it could not be. The process is akin to that of a 'journey' and is constantly emphasized as such throughout Bacon's text. Its details will later be shown by Cyrano de Bergerac (see Chapter 7), for whom the journey, already in Bacon something more than simply a metaphor for the discursive process, will be hypostatized into the potential reality of a new technological capacity.

The fundamental structure controlling Bacon's utopia is based on a movement not toward the interior but toward the exterior, toward what is different, whether the structure itself be indicated as a voyage or as an observing gaze. In that connection the voyages of Columbus, Magellan, and others were as much a symbol of a new kind of discursive habit as they were real events-in much the same way as the telescope became a generalized metaphor for a certain class of discourse. If the City of the Sun can be compared to a prey contracted and trapped in a corner, situated near the Taprobana of an already outdated geography, then New Atlantis is an octopus, situated in a New World and sending its tentacles toward both the Old World and the quite unknown.

Campanella's interlocutor dismissed the voyage itself in a word (as he did those undertaken by the Solarians). The subjective narrator of New Atlantis insists upon it. In his discourse, movement and its accompanying troubles take on what initially appears an almost inordinate emphasis:

We sailed from Peru (where we had continued by the space of one whole year), for China and Japan by the South Sea; taking with us victuals for twelve months; and had good winds from the east, though soft and weak, for five months' space and more. But then the wind came about, and settled in the west for many days, so as we could make little or no way, and were sometimes in purpose to turn back. But then again there arose strong and great winds from the south, with a point east; which carried us up (for all that we could do) towards the north: by which time our victuals failed us, though we had made good spare of them. So that finding ourselves in the midst of the greatest wilderness of waters in the world, without victual, we gave ourselves for lost men, and prepared for death. [P. 359 $]^{28}$

28. It may be objected that I am making too much of the originality of this emphasis. Andreae also begins Christianopolis with the recounting of a voyage, storm, and 
Once again the influence of the voyages of discovery is manifest. But in La città del sole dialogue placed the emphasis on intercommunication in a state of closure. Whether or not Pigaf etta's tale of Magellan was the model, the situation of Campanella's interlocutor is, like that of Pigafetta, a subsidiary one: he, like every Solarian, is a small though necessary part of a greater encompassing whole. Bacon's narrator relates and emphasizes his voyage of discovery more from the viewpoint of a Walter Ralegh directing his own ships at the Americas. He can take responsibility for what can become his own "history of the world."

Ralegh's Discoverie of Guiana, for example, is not related as one single voyage. The principal journey represented by the passage of his ship is accompanied by his own short trips along the coasts of the islands he comes across, during which he "landed in every cove." The single long voyage is narrated as though it were the sum total of many short ones, culminating in his four-hundred-mile, month-long journey up the Orinoco. That trip itself is recounted as having been preceded by those of many other explorers. A similar technique is evident in Drake's World Encompassed, whose story was published the year after New Atlantis. Single voyages without sight of land for long periods were very definitely an uneasy experience, and fifty-two days in a tempest at sea, "with great trouble, long time, many dangers, hard escapes, and finall separating of our fleet," is more awful and brings greater fear than coasting up the shores of an enemy continent, raiding the Spaniards with one small ship and vastly inferior numbers of men, and constantly facing the unknown risks of the native Indians. ${ }^{29}$ It is indeed a fact that such voyages were composed of miriad small trips: landings were constantly necessary to revictual and repair ships at sea for long periods, to explore and if possible take possession of the land, to obtain some idea of the inhabitants, and, in Drake's case especially, to raid the Spaniards. What I am suggesting here is the metaphorical value of such activities for a newly developing class of discourse.

shipwreck. There, however, it is completely allegorized: a voyage in the ship "Phantasy," across the "Academic Sea," toward true religion that has fled with "the companions whom she regarded the most faithful" (p. 144). Moreover, the island containing Christianopolis is a haven of rest, and once arrived there the sole survivor of the wreck will find himself in a city akin to Campanella's. Bacon's island is a place of constant journeying.

29. Sir Walter Ralegh, The Discoverie of the Large, Rich, and Bewtiful Empyre of Guiana ... (London, 1596), pp. 2, 12-24; Sir Francis Drake, The World Encompassed, Being His Next Voyage to That to Nombre de Dios, Formerly Imprinted . . . (London, 1628), pp. 39-40 and passim (Drake's voyage around the world took place from 1577 to 1580 ). 
The steady accumulation of such small bits and pieces is what will lead to honor and wealth. Such is ultimately Drake's goal. Ralegh makes no bones about it: "the shining glorie of this conquest will eclipse all those so far extended beames of the Spanish nation," his specific examples being Cortez "in Mexico, or Pazzaro in Peru." Discovery is worthy of kingship, and the voyager may be considered a king, concludes Ralegh, as he asserts that if Elizabeth will not send a fleet to Guiana: "I will judge those men worthy to be kings thereof, that by her grace and leave will undertake it of themselves." ${ }^{30}$ The men of Bensalem view matters and go about acquisition in much the same way: knowledge, power and gain, spiritual profit, and material utility go together.

So autonomous and self-dependent an activity carries with it its own risks. In Ralegh's case they were economic and, finally, political. Like Bacon himself, though with consequences even more disastrous, Ralegh expiated politically his collision with the entrenched order. Only a dozen years later the same opposition was to bring Galileo's case to a head: at his trial the confrontation of two different classes of conceptualization, 'science' and 'theology,' echoes the conflict elsewhere taking a political and economic form. In full awareness of such a contextual network, Descartes finds it useful, in the second part of his short treatise on what is presented as a scientific (or, at most, philosophical) method, to comment on his present inability to change the political order. The tone of the opening passage of New Atlantis may well remind us of Pascal's anguished cry before the fearful silence of unlimited space that will be heard only a short time later. Provoked by the same emerging elements, that cry is a reaction to the risks undertaken, too, by such as Ralegh, Bacon, Galileo, Descartes, or the earlier Drake.

Despite his own very real physical and spiritual risks and sufferings, that awe does not touch Campanella in at all the same way, and the interlocutor of La città del sole remains safe within the "animal of the world." The tenants of Bacon's text are very different indeed. Not only his travelers but his islanders as well experience the awe of being cast adrift upon the "vasty deep." Like Francis Fletcher, recorder of Drake's voyage, Bacon's islanders are concerned to avoid the dangers of an unknown that fascinates them.

For the moment, in New Atlantis, the voyage comes to a halt in a land in a quite unknown area of an unexplored ocean (p. 360): "in the secret conclave of . . a vast sea" (p. 374), where they enter a

3o. Ralegh, Discoverie of Guiana, pp. 94, 101. The present volume has room for only skeletal references to Ralegh. In some exemplary pages, Christopher Hill provides the meat: Intellectual Origins of the English Revolution (Oxford, 1965), pp. 131-224. 


\section{4 . The Discourse of Modernism}

welcome harbor fronting a beautiful city. Pascal's dread leads him toward his two infinities and to the disavowal of analytical science as being the choice of constraining humanity within the limits of a flawed finitude. ${ }^{31}$ That of Bacon's voyagers will produce the means to a scientific knowledge that lays claim to a potential completeness. Such knowledge will be achieved by means of such ever-renewed journeys as those composing New Atlantis. It is a 'completeness' not in the sense of an embracing totality but as an accumulation of discrete units-a totality, therefore, that is the sum of its parts and no more, following the manner of Drake's or Ralegh's quest.

In the text of New Atlantis, just when one might expect the journey to be at an end, a whole series of journeys gets under way. The initial voyage from the shelter of the old, safe world to this unknown island of Bensalem is to be repeated in several forms (though, in fact, this one is itself not the first voyage: for the reader enters in the very midst of the process, the travelers already having made the journey to Peru). It becomes the central figure of New Atlantis. Anchored in port, the sailors are not allowed to disembark, or even approach the town. It is only after several trips to and fro, after much discussion and ceremony, that the islanders permit them to land, and then only after waiting a night. From the prison their boat has become, they make the short trip that brings them to the "Strangers' House" (p. 364), where they will once again find themselves sequestered, this time for three days (p. 366). This one is a short journey in distance, but it is enormous spiritually.

Before being allowed ashore, the travelers find themselves in a no man's land, "between life and death . . . beyond both the old world and the new" (p. 367). Their habitual gestures are of no use, and they have yet to acquire new ones. They are to experience a kind of new beginning, stripped of the accoutrements of the old usages: "let us behave ourselves as we may be at peace with God," the narrator urges his companions, "and may find grace in the eyes of this people" (p. 367). They will become as children before the governor and priest of the House of Strangers, whom they regard as "gracious and parent-like" and whom they ask to accept them as "true servants" (p. $369){ }^{32}$ In a sense, the travelers have not yet landed: away from the

31. On this matter see Louis Marin, Critique du discours: Sur la 'Logique de Port-Royal' et les 'Pensées' de Pascal (Paris, 1975), esp. pp. 18-19, 103-11; and my own comments in "Sailing to Byzantium: Classical Discourse and Its Self-Absorption," Diacritics, 8, no. 2 (Summer 1978), 34-46.

32. At this period the word "parent" meant not only father and mother--or simply "progenitor" at no matter what remove-but also anyone of close kinship. It seems legitimate to interpret the word here in the former sense, for he comes as governor 
ship they are nevertheless not allowed into the city itself. When they do come forth (and even before doing so) it will be to learn an entirely new way of social and intellectual ordering, and what they will eventually be given "leave to publish ... for the good of other nations" (p. 413) is far more than the surprising information about the established order of a City of the Sun: it is a whole new way of observing and controlling the world. To be sure, they will not be permitted to reveal the whereabouts of Bensalem, even if they knew it, and the knowledge gained by the "Fathers" of Salomon's House remains their secret, but the narrator can and does bring back the elements and system making possible that knowledge.

Some of the principal marks of the system are indicated from the outset. If the travelers are to begin afresh from a sort of 'zero point' in the acquisition of knowledge ('zero' both as to the how and to the what), if they undergo a 'spiritual rebirth,' the inhabitants for their part find themselves experiencing the fear of the unknown, facing the danger that is posed by the difference of what comes from the outside. Only later is it explained to the sailors why they are initially warned off by "divers of the people, with bastons in their hands, as it were forbidding us to land" (p. 26o). They will be informed of "the laws of secrecy which [the islanders] have for [their] travellers" and of their "rare admission of strangers" (p. 370), the idea being to protect the integrity and knowledge of the island and inhabitants of Bensalem. The "interdicts and prohibitions" concerning strangers had been laid down by that enlightened lawgiver, Solamona, because he saw that the land could "be a thousand ways altered to the worse, but scarce any way to the better" (p. 381). "Perceiving the good which cometh from communicating with strangers, and avoiding the hurt" (p. 382), he had sought means to get to know foreigners without putting his own subjects to the risk of being known by them.

The discursive practice they maintain is thus marked at what is given as its points of origin-the island of Bensalem itself topographically and the King, Solamona, chronologically-by secrecy and an elitism of no uncertain kind: the island of Bensalem in respect of the rest of the world, the Fathers of Salomon's House as regards the rest of the island, the father in relation to the family. It becomes increasingly clear that the discourse of knowledge as a jour-

and priest, and he has just, at the moment the term is used, given the travelers the command not to go beyond a mile and a half from the House. It is true that after they ask him to accept them as his servants, he refers to their "brotherly love" for one another (p. 369). It is nonetheless clear that they regard him as their superior and guide. 
ney always recommencing at the end of a previous one (which we will find 'translated' by Cyrano de Bergerac into the exact form of experimentalism) depends on the secrecy of the knowledge gained and then put into play again for the next 'journey,' and upon the superiority of the enunciator of that discourse..$^{33}$ In New Atlantis these elements are laid unbashedly bare, and I will return to them shortly.

After three days in the House of Strangers, the travelers still do not leave. Instead the islanders renew those trips to and fro that characterized their wait in port, and the governor of the House comes for a series of discussions. These are no less centered on sea voyages than the account itself up to the present. On the fif th day (the fourth having been given over to their instructions), the governor relates how a mysterious "ark or chest of cedar" (p. 372) brought them by sea the word of an apostle of Christ, to which event they owe their faith: if their Christian beliefs are the foundation of their society, as they are said to be, then they in their turn are founded in a sea voyage, whose telling is a part of the travel discussions held by the governor of the House of Strangers, themselves enveloped in the journeys that compose New Atlantis. Only much later do we learn that secrecy and superiority are an integral part of this faith as well: for "Moses by a secret cabala ordained the laws of Bensalem which they now use" (p. 391). They are set apart even from other Christians-which no doubt explains why the Jews who live on the island do so in such harmony (pp. 390-91), being also a chosen race!

The following day, the governor describes to them the state of navigation in the past, the flood of the Americas, and how his country was alone in maintaining a knowledge of foreign lands and the means to go there (p. 380). He goes on to tell that one of the principal activities of Bensalem is the dispatching every twelve years of two ships to go out into the world,

appointed to several voyages; That in either of these ships there should be a mission of three of the Fellows or Brethren of Salomon's House, whose errand was only to give us knowledge of the affairs and state of those countries to which they were designed, and especially of the sci-

33. This accords precisely with analytical science as it is elaborated by Galileo, for example: see Reiss, "Espaces de la pensée discursive: Le cas Galilée et la science classique," Revue de synthèse, no. 85-86 (Jan.-July 1977), pp. 5-47. It also agrees with neoclassical juridical practice as explored by Michel Foucault, Surveiller et punir (Paris, 1975), pp. 39 ff. I do not seek to give a precise reason for their similarity here, but such elements are essential to the functioning of this class of discourse. As far as the succession of journeys is concerned, the very title page of Drake's World Encompassed is an example worthy of notice: “. . . being his next voyage . . " (see note 29 above). 
ences, arts, manufactures, and inventions of all the world; and withal to bring unto us books, instruments, and patterns in every kind. [P. 384]

After the revelation of this recurring and continuous voyage of research, the visitors, the strangers, begin to leave their "refuge" and see the country.

Ultimately, one of the "Fathers" from the House of Salomon returns, and they watch his ceremonial passage from the harbor, through the town, to some solitary retreat: "his coming is in state; but the cause of his coming is secret" (p. 395). After three more days, the narrator is admitted to his presence and permitted to join him in discussion. It takes the form of an instruction concerning the reason and justification for the House of Salomon, its activities, its journeys: "The End of our Foundation is the knowledge of Causes, and secret motions of things: and the enlarging of the bounds of Human Empire, to the effecting of all things possible" (p. 398: my italics).

The well-known passage that follows describes a veritable experimental institution with its means and experiments (pp. 398-409). Yet what is given are almost entirely descriptions of the material from which experiments could be made (which is why I have twice suggested that the content of knowledge is not given, but simply the means to achieve it). It is, affirms Cioranescu, "a veritable programme, to the extent that all programmes remain open and leave the door open behind them. It was thus that it was understood immediately: and as early as 1645 a philosophical College was founded in London, in imitation of Salomon's House, and which was the ancestor of the illustrious Royal Society." It is almost certainly too much to put the founding of the Royal Society down to the fiction of Salomon's House, but the latter's methodical repetitiveness, its continuity, and its open-endedness indeed lent themselves to such a descendant. ${ }^{34}$

34. Cioranescu, Avenir du passé, p. 149. In his introduction to Christianopolis, Held claims that Bacon had taken the idea of his center of learning from Andreae (pp. 41-74). This is nonsense. Andreae's center owes more to the kind of humanistic science of Paracelsus than to anything that comes later: it seeks out "the forces of agreement and opposition ... poisons and antidotes ... things beneficial and injurious to the several organs of man's body" (p. 200). It investigates "according to their characteristic marks and signs thousands of herbs, classifying them with respect to diseases" (p. 201). Others have offered different models: see, e.g., Rosalie L. Colie, "Cornelis Drebbel and Salomon de Caus: Two Jacobean Models for Salomon's House," Huntington Library Quarterly, 18 (1955), 245-6o. Arthur Johnston observes that the "germ of this institute" is to be found in Bacon's own work: the Gesta Grayorum of Christmas 1594 and the Commentarius solutus of 1608 (Francis Bacon, The Advancement of Learning and New Atlantis, ed. Arthur Johnston [Oxford, 1974], p. x n. 16). Charles Webster, The Great Instauration: Science, Medicine, and Reform, 1626-166o (London, 1975), passim, seems to have given the definitive word on the matter, showing how 


\section{8 . The Discourse of Modernism}

After the description, and after the Father has left the narrator with a reward of two thousand ducats, the tale comes to its abrupt close. To be more exact, it does not end, but leaves off the telling with the words, "the rest was not perfected" (p. 413). Spedding comments that Bacon had intended to show "a model political constitution, as well as a model college of natural philosophy" (p. 350), but asserts at the same time that "though not finished [the work seems] to have been intended for publication as it stands" (p. 349). This is not, I think, as contradictory as it looks on the surface: for the non-end does serve as an explanation of sorts of the series of voyages within voyages and suggests the direction indicated by the inductive discursive movement. It is a journey outward whose conclusion can always be only temporary-a time for the contemplation of the new knowledge gained before beginning once again (and always) a subsequent journey.

The narrator himself has followed just this pattern: a journey untold, followed by a year in Peru; a journey followed by the confinement in port on shipboard, "between life and death"; a journey to the House of Strangers, followed by "servitude" during three days; a journey to the solitary abode of the "Father" from Salomon's House, and the instruction of a new means and system of knowledge; a further untold journey home, and the writing of New Atlantis. The story, in a way, could not be otherwise. The experimental (analytico-referential) discourse must be open-ended and repetitive. The continual voyages, their halts for 'meditation,' the arrival at an empirical knowledge that leads the narrator into another journey, and so on ad infinitum, are the very image of the experimental discourse being elaborated throughout the period. At the same time, these elements echo the contemporary voyages of discovery and, at a different level, such general situations as the enormously increasing social mobility of the individual-a mobility at once vertical and horizontal, one of class status and geographical location. Later texts will show more clearly yet how such movement forms the very basis of their organization.

This dynamism is reinforced by what appears to become an essential element in the discourse of analysis and reference, in addition to

the Royal Society was a gradual consolidation of a whole network of intellectual activists chiefly in Oxford and London. I am not concerned with protecting Bacon's originality but with observing the fundamental distinction to be made between different discourses and their goals. Like the Solarians, the inhabitants of Christianopolis are undertaking to decipher the world. What we have there is not Galileo (or Bacon) but Fiolxhilde, Paracelsus, or Agricola. 
secrecy and the superiority of the enunciator of discourse: the use throughout the fiction of the first person, both singular and plural. Such use may be contrasted with the almost exclusive use in La città del sole of the third person-despite its superficial use of dialogue (such dialogue being, in a manner of speaking, 'collective' rather than 'personal'). The usage corresponds exactly to what we find in Galileo, in Descartes, and in other writings of Bacon: the new scientist imposes the discursive $I$ upon the world outside him. He is a conqueror enforcing his will, a man ravishing a woman: whether it be Galileo tearing the veils concealing the moon's nakedness in the Sidereus nuncius, diverse later grammarians disrobing a language they speak of as a woman, or Sir Walter Ralegh bluntly asserting the future rape of a yet relatively untouched part of South America:

To conclude, Guiana is a countrey that hath yet her Maydenhead, never sackt, turned, nor wrought, the face of the earth hath not beene torne, nor the vertue and salt of the soyle spent by manurance, the graves have not beene opened for gold, the mines not broken with sledges, nor their Images puld down out of their temples. It hath never been entred by an armie of strength, and never conquered or possesed by any Christian Prince. ${ }^{35}$

That was just the attitude that had been savagely attacked by Montaigne in his essay "Of Coaches" only a few years before (1588), and utterly condemned by Las Casas in his Brief Relation of 1552, written against Spanish behavior in the "Indies."

In the Passions de l'âme, Descartes will hypostatize that $I$ of discourse into the psychological self of possessive individualism, as Hobbes will into the political self in the almost simultaneous $D e$ cive. In literary discourse such a development will be paralleled by a new writing of introspection, revealed in "a minute examination of psychological detail [that] can make a gradual impression only on the consciousness of a persistent and solitary reader." ${ }^{.36}$ When that occurs, the secrecy, the superiority, and the power of the enunciating $I$ have all been occulted: a new class of discourse has become dominant, thanks to the concealing of certain elements essential to the discur-

35. Ralegh, Discoverie of Guiana, p. 96. On Galileo, see my "Espaces de la pensée discursive," pp. 15-17, and on the grammarians, my "Du système de la critique classique," XVIIe Siècle, 116 (1977), 3-16.

36. Paul Delany, "King Lear and the Decline of Feudalism," PMLA, 92 (1977), 438; also his British Autobiography in the Seventeenth Century (London, 1969), passim, and pp. 19-23 for the relation between individualism, autobiography, and social mobility. See also Hill, Intellectual Origins, pp. 220, 295-96 (discussing especially Ralegh's poetry). 
sive inception, but whose visibility would put in doubt the possibility of such discourse (if only for ethical or epistemological reasons).

Bacon's seeker is an individual $I$ in search of knowledge that will allow him to enlarge "the bounds of human empire." It is a way to personal possession, with all the difficulties, hesitations, and fears that may be involved. The Fellows of the House of Salomon are searching for personal honors and riches as much-or more-as they are enrichers of the general store of knowledge: "For upon every invention of value we erect a statua to the inventor, and give him a liberal and honourable reward" (p. 412). It is significant that the narrator's own 'discoveries' (what he can reveal on returning home) should be rewarded in advance by a sum of money (p. 413).

It is certainly the case that Campanella's Solarians also received rewards: but in the first place all could win honors, and in the second such honors were entirely symbolic. In Bensalem such rewards take the form of material possessions, the very image of what is made possible by the invention itself. One may well be reminded of the aims of sailors from Columbus to Magellan, from Vespucci to Drake and Ralegh. Some three hundred years later, in 1896 (and almost simultaneously with Frege's 're-telling' of the telescope metaphor), Charles Sanders Peirce was to write: "But it is easy to see that the only kind of science the principle [of individual greed] would favour would be such as is immediately remunerative with a great preference for such as can be kept secret, like the modern sciences of dyeing and perfumery." And he continues by noting the difference between a science of the kind sought by Kepler and that of his successors:

Kepler's discovery rendered Newton possible, and Newton rendered modern physics possible. ... But Kepler's discovery would not have been possible without the doctrine of conics. Now contemporaries of Kepler-such penetrating minds as Descartes and Pascal-were abandoning the study of geometry (in which they included what we now call the differential calculus, so far as that had at that time any existence) because they said it was so UTTERLY USELESS. ${ }^{37}$

As a commentary upon the mode of activity of the Fathers of the House of Salomon, this is clear enough. Kepler's science had so little of the gainful or secret about it that he was on the one hand always

37. Charles S. Peirce, Philosophical Writings, ed. Justus Buchler (1940; rpt. New York, 1955), p. 48. 
out of money, and on the other had no hesitation, in the Astronomia nova of 1609 , in leading his reader through his incorrect calculations concerning the movement of Mars before arriving at the correct ones. That is unimaginable in a Galileo, for example, who uses his discoveries for purposes of profit and who never communicates (except unawares) any but his correct, final conclusions. To do otherwise would be to reveal the fallibility of the enunciator of the discourse-a revelation that Peirce will consider essential to the activity of science. Like Galileo, the Fathers of Salomon's House reveal only such finished artifacts as they choose, "such profitable inventions as [they] think good" (p. 412, the term "profitable" being used in the sense of 'useful' rather than 'financially rewarding,' though it is also that for its inventor).

It goes without saying that such remarks as these are intended not to make a pejorative moral judgment but to stand as statements of fact concerning the establishment of the hegemony of a particular class of discourse. Opponents of the new philosophy raised many questions of this kind. Montaigne had objected half a century before (in the 1588 edition of the Essays), in a voice echoing that of Las Casas and to be left behind like the Spanish Dominican's, that the new knowledge might have been used for a kind of new beginning, to benefit from a contact with "minds yet so pure and new," to elevate both itself and its potential pupils among the newly discovered natural souls of the Americas, conspicuous for their "yeelding naturall beginnings." Instead of which, the emphasis was being placed entirely upon increasing wealth and property: the Cortezes and the Pizzaros, the Cartiers, Drakes, and Raleghs shared an attitude utterly typical. Though less strong than the bitter fury that informed Las Casas's life work, the outrage expressed by Montaigne is far greater than later objections could be, once the new discourse had become firmly established:

contrarywise, we have made use of their ignorance and inexperience, to drawe them more easily unto treason, fraude, luxurie, avarice and all manner of inhumanity and cruelty, by the example of our life and patterne of our customes. Who ever raised the service of marchandize and benefit of traffick to so high a rate? So many goodly cities ransacked and razed; so many nations destroyed and made desolate; so infinite millions of harmelesse people of all sexes, states and ages, massacred, ravaged and put to the sword; and the richest, the fairest and the best part of the world topsiturvied, ruined and defaced for the 
traffick of Pearles and Pepper: Oh mechanicall victories, oh base conquest. Never did greedy revenge, publik wrongs or generall enmities, so moodily enrage, and so passionately incense men against men, unto so horrible hostilities, bloody dissipation, and miserable calamities. ${ }^{38}$

Like so many others of the sixteenth century, Montaigne's was a voice of passage, no doubt admired, but now long overcome by the dominant discourse of analysis and reference. Nonetheless, voices were raised even from within that dominance. Cromwell himself, in the manifesto of 1655 (perhaps written by Milton), justified his war against Spain with the claim to be avenging Spanish cruelty against the American Indians, on the grounds that such cruelty constituted an attack on all mankind. The Protector's assertion, of course, implied a convenient forgetfulness with regard to the excessive cruelty visited by his own troops upon the Irish. The emphasis on utility and profitability, if less that on secrecy, is just what Meric Casaubon, Prebendary of Canterbury, was to criticize in the new experimentalism. Writing to Pierre Du Moulin, a Letter Concerning Natural experimental Philosophie, and some books lately set out about it, published at Cambridge in 1669, Casaubon strongly attacks the two chief champions of the Royal Society, Thomas Sprat and Joseph Glanvill, for measuring utility by a strictly "materialistic standard." If, he argues, utility was "found only in what affords the necessities and conveniences of life, brewers and bakers, smiths and veterinarians would have to be considered equal or superior to those who have been regarded as the great lights of learning." ${ }^{39}$

Casaubon's essential criticism is aimed at the division of the material and the spiritual, the separation of the physical from the moral and aesthetic. His view is typical of the humanism preceding what Haydn called the "counter-Renaissance," and still alive in such writers as Tesauro and the late Paracelsans. Indeed, the Prebendary's opposition to simply utilitarian specialization (the form eventually to be taken by that initial emphasis on "secrecy") and to the consequent fragmentation of knowledge was not without its antecedent justifica-

38. Michel de Montaigne, Essays, tr. John Florio, intro. L. C. Harmer, 3 vols. (1910; rpt. London and New York, 1965), III.144 ("Of Coaches," III.vi). Florio's translation is not a model of accuracy, but is not unfaithful to Montaigne's tone, if anything rather exaggerating the outrage.

39. The quotation is from Richard Foster Jones, Ancients and Moderns: A Study of the Rise of the Scientific Movement in Seventeenth-Century England, 2d ed. (St. Louis, 1961). Jones paraphrases and comments on Casaubon's Letter at some length, pp. 241-44. For the Cromwell reference, see Christopher Hill, Some Intellectual Consequences of the English Revolution (Madison, 1980), p. 86. 
tion in the writings of Bacon himself. The Chancellor always insisted that no object of knowledge could be studied in isolation. He went so far as to assert, indeed, that to try to do so would be fatal to the advancement of learning. In 1642 Comenius was making identical assertions. Nonetheless, the conservative nature of Casaubon's intervention is suggested by the fact that his "correspondent" had been one of the royalist theorists in the vituperative dispute with Milton, whose Pro populo anglicano defensio secunda of May 1654 had been directed specifically against anti-regicide arguments published by $\mathrm{Du}$ Moulin in $165^{2}$.

These fundamental aspects of utility, profit, and secrecy run over into other areas of human activity. It is a natural corollary to such a view of the scientific activity that the wise men of New Atlantis do not consider the state as a harmonious organism, on the model, for example, of the City of the Sun and the Solarians' view, or, looking a bit further back, on the model of the conjunctive polity of the Middle Ages. By the scientists of Salomon's House, the state is seen almost as a foreign body of which they are scarcely a part: they "take all an oath of secrecy, for the concealing of those [inventions] which [they] think fit to keep secret: though some of those [they] do reveal sometimes to the state, and some not" (p. 411).

Indeed, the state is composed, like any form of discursive knowledge of this kind, of discrete, separate units. Of these the family is the principal, being related to the whole much as is the House of Salomon: whenever a father lives to see "thirty persons descended of his body alive together, and all above three years old" (p. 386), then that family unit is celebrated. The father becomes judge, priest, prince, and chief celebrant of the feast, receiving from the King, just as do the inventors in an analogous situation, "many privileges, exemptions, and points of honour" (p. 388). Monogamous individual marriage (as opposed, for example, to the Solarians' collective breeding system) is praised as the essential maintainer of such a unit (pp. 392-94). One is irresistibly reminded, again, of Ralegh's conquering kings sailing to take Guiana, or of Machiavelli's process of princely power through a gradual accumulation of possessions.

We can see that the "political constitution" that was never written down as such is in fact already inscribed in the particular discursive order of which secrecy, willful hierarchy, and the power of the enunciating $I$ are such essential elements. There is little doubt that Uscatescu is right in observing: "Machiavelli's conception of politics was in agreement with the fundamentals of the Baconian experi- 


\section{4 - The Discourse of Modernism}

mental philosophy. In addition, the idea Bacon has of politics is substantially utilitarian and activist." ${ }^{40}$ There is nothing new in a statement of identity between the politics of possessive individualism and the scientific stance of experimentalism: "we do publish such profitable inventions as we think good" (p. 412: my italics). It is, remarks Charles Webster, "only a slight exaggeration to regard Baconianism as the official philosophy of the [Puritan] Revolution." And the same author notes the natural alliance between the new economic theorists, of whom William Petty would be typical, and the Baconian natural philosophers. ${ }^{41}$ All these discourses are types of the developing analytico-referential dominance. That the structure of Bacon's sea voyage should illustrate such an institution is scarcely cause for surprise. It does need emphasizing, though, that this is revealed not only at the level of 'content' (as Spedding and others have it): the entire form of the fiction is built up from the impulse to control the other, to impose the self-in secret.

The fictions of Campanella and Bacon reveal a fundamental difference of impulse. The access to both is by a long sea voyage, certainly; but how quickly does Campanella jump the southern ocean to go to earth in his island, bound tight in its circular foundations, closed of $\mathrm{f}$ as far as possible from the exterior expanse of the ocean. That voyage is essential to the entire ordering of New Atlantis, and mark of a new discourse of knowledge and power. The City of the Sun seeks to create (indeed, has created) a fixed world where the elements of knowledge, with their analogies and union with the divine, have been acquired and sealed on its walls.

Campanella's structure resembles the Platonic, then, in a way more essential than the mere similarity of its outward shape. And that is in the very impulse of its functioning. In the Republic knowledge is equated with being itself: "And knowledge is relative to being and knows being." ${ }^{42}$ Such 'absolute' knowledge-knowledge of Unity, of Idea-is by definition accession to a 'total being' in something like the sense we tried to grasp when speaking of medieval discursive practices. Translated into Campanella's terms, the perfect knowledge sought by the city will be quite precisely coincident with that identity of the self with God attained at the altar of Sol.

Just as Plato's State is ideal because it is at once the homologue and

40. George Uscatescu, Utopía y plenitud histórica (Madrid, 1963), p. 89. Johnston, with others, tries to distinguish between the scientific and political orders sought by Bacon (ed. cit., p. viii). It is clear that such an argument strikes me as untenable.

41. Webster, The Great Instauration, pp. 25, 447-48.

42. Plato, Republic, 477-Jowett translation. 
the analogue of the ultimate guardian, the perfect philosopher and earthly embodiment of the Divine (and one can, then, speak of an identity), because its perfect harmony is that of the just soul (in the absolute sense given to the term and concept 'Justice' by Plato), so also with Campanella's city. Moreover, though it is directed at such a unity with the Divine, it can do so only in response to an aura that proceeds from the Divine. Its light, as we saw earlier, does not proceed from within. It is entirely receptive, and its light is received from without and beyond: "Then the sun is not sight, but the author of sight who is recognized by sight." ${ }^{43}$

Bacon has taken each of these terms and inverted them. For him, in accordance with a remark in The Advancement of Learning, "the truth of being and the truth of knowing are one, differing no more than the direct beam and the beam reflected." This may well be, but however close they are kept, he has nonetheless separated them: knowledge and being are split into two separate fields, and for Bacon their generalization into concepts will be the responsibility of two different types of discourse. For Campanella and Bruno, as for Plato, being is knowing; for Bacon knowing leads toward being: as for Descartes, cogito ergo sum. Knowing is action first of all, and it can only lead to being insofar as such being is concerned with the interaction of individuals responsible for their own choices. It is precisely thus that Hobbes will be able to found the new society of Leviathan, advancing the claim that his science of human society starts with the same punctual units and the same facts of their motion as any other science of mechanics: the equation of self-knowing-being is that of discrete unit-action-society.

Furthermore, the sun of New Atlantis is provided by the human mind, a mind that is no longer the mere recipient of light, but rather its imposer. Descartes will remark that in the power of his will man is the equal of God; Bacon writes that "the spirit of man is as the lamp of God, wherewith he searcheth every secret." ${ }^{44}$ The biblical encouragement is put into practice in Bensalem. Salomon's House, the "noblest foundation (as we think) that ever was upon the earth; and the lanthorn" of the island (p. 382) is rather a caster of light than a receiver of it. Its pride is a natural history, written by Solomon and lost to the rest of humanity, that contains the "history" of "all the plants from the cedar of Libanus to the moss that groweth out of the wall, and of all things that have life and motion" (p. 383). Such knowledge of

43. Ibid., 5o8b.

44. Filum labyrinthi, in The Works, VI.422. 


\section{6 - The Discourse of Modernism}

external nature is "Light," but it is a light that must be sought by an active process: the purpose of the Fathers from Salomon's House is to find "God's first creature, which was Light: to have light (I say) of the growth of all parts of the world" (p. 384).

Thus it is that the twelve seekers who go out from Salomon's House are known as "Merchants of Light" (p. 410), while the three members of the House who are responsible for the fomulation of "new experiments of a higher light" are known as "Lamps" (p. 411). The both seek and produce light, so that even the Atlantans' knowledge of the Divine is brought to them by their scientists: "It so fell out that there was in one of the boats one of the wise men of the Society of Salomon's House, which house or college (my good brethren) is the very eye of this kingdom" (p. 371). Faith, then, is received through science, not the other way about. The eye marks the distance of the discourse of analysis and referentiality from the object it wishes to grasp and know: we are back to the import of the telescope. This is a very far cry from the college as soul that we find in Christianopolis, or from the temple of The City of the Sun. Salomon's House is "the very eye of this kingdom." It is a very self-contained eye, quite unlike the reactive soul of Plato's State or Campanella's City. It is the very eye that sends forth its beams of light up the telescope to illuminate the object of its gaze that is so dramatic an ingredient of the Sidereus nuncius. ${ }^{45}$

Bacon's Bensalem is an island trying to have the best of both worlds: it too has its well-placed and long-lasting foundations, protected from the threats menacing it from the ocean. But Bensalem is constantly caught up in its journeying abroad, and its traveling sages receive the most honor and the greatest rewards. It is a city on the edge of Pascal's empty space, constantly angled toward flux, danger, and the transitory: "The being destined to water is an ever-changing being [un être en vertige]. At each moment he is dying, some part of his substance is endlessly crumbling away." 46

In that, the inhabitant of Bensalem is similar to Duracotus; but now, instead of acting against the analytico-referential discourse, he has become its image. What may perhaps be represented by these islands, lying in the midst of uncharted seas, is the attempt to seize the discursive process of intellection, a certain form of consciousness. Each narrator, it may be, sails through "an oneiric experience"

45. See Reiss, "Espaces de la pensée discursive," pp. 13-15.

46. Gaston Bachelard, L'eau et les rêves: Essai sur l'imagination de la matière (Paris, 1942), p. 9 . 
toward "the revelation of his reality and of his identity." ${ }^{47}$ But this should not confuse us into thinking that therefore these consciousnesses are the same: consciousness is the product and embodiment of discourse, itself the ongoing development of sign processes. As Vološinov has written: "consciousness itself can arise and become a viable fact only in the material embodiment of signs. The understanding of a sign is, after all, an act of reference between the sign apprehended and other, already known signs; in other words, understanding is a response to a sign with signs." ${ }^{48}$

The utopian structure may best be understood, it would here appear, as the objectivization of a class of discourse into a particular type of content. Between La città del sole and New Atlantis the difference is clear: the first may be compared most nearly to the text of Kepler's Dream, the second to the mode of its notes. They are different responses to a moment of crisis we saw already couched in the terms of More's Utopia, a text potentially containing them both but unable to make any decision-or even to conceive of such a decision, locked as it was in the contradictions of an altogether different discursive space. Utopia performed the moment of crisis, the Somnium revealed the emergence of a solution, Campanella's and Bacon's texts illustrate a further development: the separation and delimiting of the old contradictions. La città del sole is linked to a discursive past. New Atlantis opens up toward a new discursive future.

47. Ibid., p. 134 .

48. Vološinov, Marxism and the Philosophy of Language, p. 16. 